\title{
The Persecution in Lugdunum and the Marytyrdom of Irenaeus in the Eyes of Gregory of Tours
}

\author{
Satoshi Ohtani \\ Tohoku University (Sendai) \\ sohtani198o@gmail.com
}

\section{Summary}

In this article, I shall explore how Gregory of Tours, the Gallic sixth-century historian and bishop, understood the persecution in Lugdunum (present-day Lyon) in 177. In Libri historiarum decem and Liber in gloria martyrum, Gregory briefly describes the persecution and names the martyrs, including Irenaeus, the bishop of Lugdunum. According to ancient historians, however, Irenaeus was not a martyr. It has been established that Gregory's list of martyrs was derived from Eusebius' Antiquorum martyriorum collectio, of which only fragments had survived in Gregory's time. In addition, the translation of Eusebius' Historia ecclesiastica into Latin by Rufinus altered the passage referring to Antiquorum martyriorum collectio. Given the corruption of texts that occurred during late antiquity and the early Middle Ages, another image of the persecution in Lugdunum formed in the eyes of Gregory.

\section{Keywords}

Lugdunum - Gregory of Tours - Irenaeus - Eusebius - Rufinus - Historia ecclesiastica Tours

The persecution in Lugdunum occurred in 177, during the reign of the Roman emperor Marcus Aurelius. ${ }^{1}$ Immediately after the persecution, the churches of

1 J.W.Thompson, "The Alleged Persecution of the Christians at Lyons," AJT, 16 (1912), pp. 359-384, dated the event at the late third century. See T.D. Barnes, "Eusebius and the Date of 
Lugdunum and Vienne wrote a report to the churches in Phrygia and Asia Minor. The sole surviving account of this persecution is a letter preserved in book five of Eusebius'Historia ecclesiastica. ${ }^{2}$ In the sixth century, Gregory of Tours (538?-594) wrote a Gallic history from the time of the Christ to the sixth century. In this book, called Libri historiarum decem or Histortia Francorum, he refers to the persecution in Lugdunum. However, his account is surprising for people aware of Eusebius's ancient testimony on the matter. Gregory describes the persecution as follows:

But also in Gallia, many people were crowned with heavenly jewels by martyrdom for the name of Christ. The history of their suffering is preserved with us faithfully to this day. In this people, there was Photinus the first bishop of the church of Lyon, who was punished by the various punishments and suffered for the name of Christ. However, the most blessed Irenaeus, the successor of the martyr, was sent by blessed Polycarp, and sparkled with the wonderful power. In a short time, he makes the city to the one of the Christian town by the power of Dominus and his own preaching. But once the persecution occurred, the devil exercised the tyrant and made that massacre, they had murdered many Christians on the account of their confession of the name, so that floods run through the streets by the blood of the Christians. We could not know their number or name, but the Lord scribes their names in the book of life. Blessed Irenaeus was butchered in the various persecutions and dedicated to the Lord Christ through the pains of martyrdom. After this, forty-eight mar-

Martyrdoms," in: Les Martyrs de Lyon (177), ed. by M.J. Rouge and M.R. Turcan, Colloque international du Centre national de la recherche scientifique, Lyon, 20-23 Septembre 1977 (Colloque internationaux du Centre national de la recherche scientifique, 575), Paris, 1978, pp. 137-143; and R.M. Grant, "Eusebius and the Martyrs of Gaul," in: Les Martyrs de Lyon (177), ed. by Rouge and Turcan, pp. 129-136.

2 Eusebius also jotted down the information about the persecution in Antiquorum martyriorum collectio, but it was scattered (see later discussion). Besides, there was a reference of the persecution in Gallia in Eusebius and Jerome's Chronicon, although it was arranged under 167. When Eusebius wrote Chronicon, he might have possessed incomplete information about the persecution. See Grant, "Eusebius and the Martyrs of Gaul," pp. 129-130. See also D.S. WallaceHadrill, "The Eusebian Chronicle: The Extent and Date of Composition of its Early Editions," JTs, n.s. 6 (1955), pp. 248-253. Eusebius, Hist. eccl. 5.1.4, 36, 62; 5.2.1; and 5.5-6; Eusèbe de Césarée. Histoire ecclésiastique, Livres V-VII, ed. by G. Bardy (SC, 41), Paris, 1955, 7, 15, 22, 23, and 29-32, wrote that he omitted passages from the letter from Lugdunum. 
tyrs suffered their fate, and we read that the first of them was Vectius Epagatus. $^{3}$

The forty-eight martyrs, including Vectius Epagatus (Vettius Epagatus) and Irenaeus, are also referred to by Gregory in Liber in gloria martyrum:

These are the names of the forty-eight martyrs who are said to have suffered in Lyon:Vettius Epagatus, Zaccharias, Macharius, Alcipiadis, Silvius, Primus, Alpius, Vitalis, Comminius, October, Philominus, Geminus, Iulia, Albina, Grata, Aemilia, Postumiana, Pompeia, Rodonae, Biblis, Quarta, Materna, Elpen ipsa Stamas. These were who condemned to the wild beasts: Sanctus and Maturus, Alexander, Ponticus, Blandina. These are who gave up their lives in prison: Arescius, Photinus, Cornelius, Zotimus, Titus, Zoticus, Iulius, Aemelia, Gamnitae, Pompeia, Alumna, Mamilia, Iusta, Trifimae, Antonia, and blessed bishop Photinus. A wicked judge decreed that their holy bodies be thrown into a fire and then ordered their burned ashes to be sprinkled on the Rhone river .... So the glorious bishop Photinus, who presided as bishop for Lyon, was perfected by martyrdom, and as a result of the merit of his noble struggle he was transported to heaven. Irenaeus, a man worthy of his predecessor's merit and holiness, succeeded as bishop and also died as a martyr. ${ }^{4}$

3 Gregory of Tours, Libri historiarum decem 1.28-29; Gregorii Turonensis Opera, Teil 1: Libri historiarum $X$, ed. by B. Krusch (MGHSS rer. Merov, 1/1), 2nd edn, Hannover, 1951, pp. 21-22: "Sed et in Galleis multi pro Christi nomine sunt per martyrium gemmis caelestibus coronati; quorum passionum historiae apud nos fideliter usque hodie retinentur. Ex quibus et ille primus Lugdunensis ecclesiae Photinus episcopus fuit, qui plenus dierum, diversis adfectus suppliciis, pro Christi nomine passus est. Beatissimus vero Hireneus, huius successor martyris, qui a beato Policarpo ad hanc urbem directus est, admirabili virtute enituit; qui in modici temporis spatio praedicatione sua maxime in integrum civitatem reddidit christianam. Sed veniente persecutione, talia ibidem diabulus bella per tyrannum exercuit, et tanta ibi multitudo christianorum ob confessione dominici nominis est iugulata, ut per plateas flumina currerent de sanguine christiano; quorum nec numerum nec nomina collegere potuimus, Dominus enim eos in libro vitae conscipsit. Beatum Hirenaeum diversis in sua carnifex praesentia poenis adfectum Christo domino per martyrium dedicavit. Post hunc et 48 martyres passi sunt, ex quibus primum fuisse legimus Vectium Epagatum." The English translation of Libri historiarum decem is author's own translation.

4 Gregory of Tours, Liber in gloria martyryum 48-49; Gregorii Turonensis Opera, Teil 2: Miracula et Opera Minora, ed. by B. Krusch and W. Levison (MGHSS rer. Merov, 1/2), 2nd edn, Hannover, 1969, pp. 71-72: "Quadraginta octo vero martyrum nomina, qui Lugduno passi dicuntur, haec sunt: Vettius Epagatus, Zaccharias, Macharius, Alcipiadis, Silvius, Primus, Alpius, Vitalis, Comminius, October, Philominus, Geminus, Iulia, Albina, Grata, Aemelia, Postumiana, 
The names of Photinus, bishop of Lugdunum (Photinus episcopus), and Vectius Epagatus in Gregory's Libri historiarum decem, as well as the names of Vettius Epagatus, Alcipiadis, Biblis, Sanctus, Maturus, Alexander, Ponticus, Blandina, and Bishop Photinus in Gregory's Liber in gloria martyrum, are matched with the names of martyrs whom Eusebius referred in his Historia ecclesiastica as the martyrs of Lugdunum in 177 (See table 1). Therefore, both accounts by Gregory above seem to refer to the persecution and martyrdoms in 177. However, there is a problem in the description of Irenaeus, the successor of Bishop Photinus.

In Eusebius' Historia ecclasiastica it is stated that, because Bishop Photinus (or ПоӨвıvós) was martyred, the imprisoned martyrs sent the presbyter Irenaeus to Eleuterus, the bishop of Rome, with their letter of recommendation. ${ }^{5}$ The recommendation was for the ordination of Irenaeus as the new bishop of Lugdunum. The ordination of Irenaeus might have occurred after the persecution, or at least after the death of Photinus, if it occurred during the persecution in Lugdunum of 177 (in Hist. eccl. 5.5.8 a similar situation is confirmed). Furthermore, after the citation of the letter from the church of Lugdunum, Eusebius marks the boundary between the citation and the next episode by saying: "But these events took place under Antoninus." ${ }^{\prime 6}$ Further, Eusebius gives an account of the incident where Irenaeus wrote to Victor, the bishop of Rome, about the argument of the date of Easter, urging Victor not to excommunicate the churches of Asia. ${ }^{7}$ Since Eusebius gives the date of the start of Victor's episcopate as 189 (the tenth year of the reign of Commodus), ${ }^{8}$ it is clear that as far as

Pompeia, Rodonae, Biblis, Quarta, Materna, Elpenipsa, Stamas. Hii autem beatiis traditi sunt: Sanctus et Maturus, Alexander, Ponticus, Blandina. Hii sunt qui in carcerem spiritum reddiderunt: Arescius, Photinus, Cornelius, Zotimus, Titus, Zoticus, Iulius, Aemelia, Gamnitae, Pompeia, Alumna, Mamilia, Iusta, Trifimae, Antonia et beatus Photinus episcopus. Quorum sancta corpora iudex iniquus igni tradi praecepit exustaque in Rodanum pulvera iussit spargi ... Igitur martyrio consummatus gloriosus Photinus episcopus, qui Lugdunensi praefuit urbi sacerdos, per certaminis nobilis meritum invectus est caelo. Cui et merito et sanctitate condignus Hereneus successit episcopus, per martyrium et ipse finitus." English translation in Gregory of Tours: Glory of the Martyrs, trans. by R. Van Dam [тTH, 4], Liverpool, 1988.

5 Eusebius, Hist. eccl. 5.4.1-2; SC, 41.27-28.

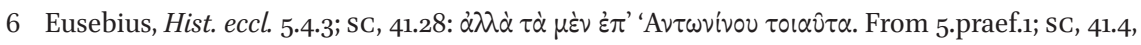
we learn that Antoninus Verus must be Marcus Aurelius, who ruled from 161 to 180 , since Lucius Verus did not reign for seventeen years. It seems Eusebius was somewhat confused between the two adopted brothers, since he correctly states at 5.5.1; SC, 41.29, that it was his brother Marcus Aurelius who fought against the Sarmatians. The problem is that there was no seventeenth year of Antoninus [Lucius] Verus' reign.

7 Eusebius, Hist. eccl. 5.24.9-11; SC, 41.69.

8 Eusebius, Hist. eccl. 5.22.1; SC, 41.65. 
Eusebius was concerned, Irenaeus survived till the 19os at least, and was not a martyr during the persecution in 177 .

\section{$2 \quad$ Previous Studies and Agenda of the Article}

Was Irenaeus a martyr (in 177)? Most scholars answer in the negative. Irenaeus was excluded from the Vatican's martyr list by the works of previous scholars in the twentieth century. Martyrologium Romanum, which included the name of Irenaeus, was made around 1584-1585 by order of Pope Gregory VIII. This martyrologium depends heavily on the martyrology of Ushard, a monk of the ninth century. ${ }^{9}$ According to Jacque Dubois, with regard to the martyrdom of Irenaeus, Ushard used the martyrology compiled by Florus in the ninth century to determine the date of Irenaeus' martyrdom. ${ }^{10}$ Henri Quentin has clarified that Florus' martyrology depends on Gregory of Tours' Liber in gloria martyrum 29, and Jerome's De uiris illustribus $35{ }^{11}$ and pointed out that Florus used the text (which Quentin calls "Martyrology of Lyon") that is included in the Latin manuscript Ms lat. 3879 in the Bibliothèque nationale de France in Paris. ${ }^{12}$

Ms lat. 3879 , written in 8o6, refers to Irenaeus as follows:

IV Kl. Iul. Lugduno Galliae, natale sancti Irenaei episcopi: qui persecutione Severi, post multa tormenta, inter quae ab Angelo meruit confortari, gloriosam martyrii accepit coronam. Corpus eius a Zacharia presbytero in crypta conditum est. ${ }^{13}$

Van der Straeten found the source of this verse, ${ }^{14}$ a text called Passio Irenaei, in the Farfa foundation MS 29 (ninth century, Biblioteca Nazionale Centrale,

9 R. Aigrain, L'hagiographie. Ses sources, ses méthodes, son histoire, Poitiers, 1953, pp. 91-93.

10 J. Dubois, Le martyrologe d'Usuard. Texte et commentaire (Subsidia hagiographica, 40), Brussels, 1965, pp. 256-257. Cf. J. Dubois and G. Renaud, Édition pratique des martyrologes de Bède, de l'anonyme Lyonnais et de Florus (Institut de recherche et d'histoire des textes Biliographies, colloques, travaux préparatoires), Paris, 1976.

11 H. Quentin, Les martyrologe historiques du Moyen Age. Études sur la formation du martrologe romain (Études d'histoire des dogmes et d'ancienne literature ecclésiastique), Paris, 1908, p. 309.

12 Quentin, Les martyrologe historiques, pp. 136-221.

13 Quentin, Les martyrologe historiques, p. 175; and Dubois and Renaud, Édition pratique des martyrologes de Bède, p. 115.

14 J. van der Straeten, “Saint Irénée fut-il Martyr?" in: Les Martyrs de Lyon (177), ed. by Rouge and Turcan, pp. 147-148. 
Rome), the reception of which he had published in $1961 .{ }^{15}$ Wilhelm Meyer concludes that the story included in this manuscript was written between 506 and 540 near Dijon. ${ }^{16}$

By comparing both texts, Van der Straeten demonstrated that Gregory of Tours viewed Irenaeus as a martyr because he believed the story of Passio Irenaei. ${ }^{17}$ In addition, Van der Straeten concludes that the discourse on Irenaeus' martyrdom has its origin in the tradition that was created in the sixth-century kingdom of Burgundy because there was no testimony of his martyrdom before the fifth century.18

Although there was a possibility of Irenaeus' martyrdom, especially during the reign of Emperor Severus (193-211), and the ancient testimony on the matter is not extant, I do not aim to provide a definite answer in this article. Instead, I tackle the problem regarding the reasons why Gregory of Tours does include Irenaeus both as a martyr and in connection with the forty-eight martyrs of 177 in Libri historiarum decem, even though he had read Eusebius'Historia ecclesiastica, which testifies to Irenaeus' survival. Moreover, Gregory used the list of the forty-eight martyrs of Lugdunum in Liber in gloria martyrum. Scholars have pointed out that this list has its roots in Antiquorum martyriorum collectio, a lost work by Eusebius. Why would Gregory have used Eusebius's information in such a conflicting manner?

\section{3} Liber in gloriam martyrum and Antiquorum martyriorum collectio

In Liber in gloria martyrum 48, Gregory names the forty-eight martyrs in Lugdunum (to be precise, three names are absent). The list of the martyrs

15 For more on the text of Passio Irenaei see J. van der Straeten, "Les Actes des martyrs d' Aurélien en Bourgogne. Le texte de Farfa," $A B, 79$ (1961), pp. 447-468. About the Farfa foundation MS 29 see A. Poncelet, Catalogus codicum hagiographicorum latinorum bibliothecarum romanarum praeterquam Vaticanae (SubHag, 9), Brussels, 1909, pp. 118-123.

16 W. Meyer, Die Legende des h. Albanus des Protomartyr Angliae, in Texten vor Beda (Abhandlungen der königlichen Gesellshaft der Wissenschaften zu Göttingen Philologisch-historische Klasse, N.F., 8/1) Berlin, 1904, pp. 3-81, at p. 71. W. Levison, "St. Alban and St. Albans," Antiquity, 15 (1941), pp. 337-359 (esp. p. 348), corroborates Meyer's statement.

17 Compare with Gregory of Tours' Liber gloria martyrum 29; MGHSS rer. Merov, 1/2.55 .

18 Van der Straeten, op. cit, pp. 148-152. Tertullian, Hippolytus, Eusebius, Jerome, and Epiphanius never refer to the martyrdom of Irenaeus. In Jerome, Commentarii in Esaiam 17.64 (4.5); Hieronymus Commentariorum in Isaiam libri XII-XVIII. In Esaiam paruula adbreuiatio, ed. by M. Adriaen and G. Morin (CCL, 73A), Turnhout 1963, 735, there was a verse referring to Irenaeus - "Irenaeus, episcopus Lugdunensis et martyr" - but it is suspected to have been an interpolation. 
originates from the letter the churches of Lugdunum and Vienne wrote. The letter is partly cited by Eusebius in Historia ecclesiastica 5 . Eusebius has been recorded to have written another book, titled Antiquorum martyriorum collectio

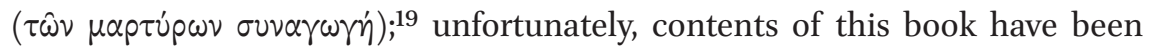
scattered and scholars have to speculate as to its original form. ${ }^{20}$

Although the original form of Gregory's list of martyrs is unknown, he could not have been aware that his list was attributed to Eusebius' Antiquorum martyriorum collectio. This is because it is possible that the list he got was a fragmented one from the original, and Gregory seems not to have been aware of a common point between his list and Eusebius' one. Eusebius often refers to Antiquorum martyriorum collectio in his Historia ecclesiastica (which, of course, Gregory read). He mentions Antiquorum martyriorum collectio twice - before describing the persecutionin Lugdunum and at the end of the narration:

Since the whole record of its complete treatment has been embodied in our collection of martyrs,... ${ }^{21}$

What need is there to transcribe the list of the martyrs in the above mentioned document, some consecrated by beheading, some cast out to be eaten by the wild beasts, others who fell asleep in the jail, and the number of the confessors which still survived at that time? For whoever wishes can read the full account by taking the description which has been included in our collection of martyrs, as I said before. ${ }^{22}$

See Eusebius, Hist. eccl. 5.4.3; sc, 41.28.

Attempts to reconstruct the book extend back to the nineteenth century. See M. Hirschfeld, "Zur Geschichte des Christentums in Lugdunum vor Constantin," Sitzungsberichte der königlich Prußischen Akademie der Wissenschaften zu Berlin, 14 (1895), pp. 381409, at p. 385; and J.B. Martin, "Liste des Martyrs de Lyon," Bulletin historique de diocè de Lyon, 1 (1990), pp. 22-26. See also G.D. Andres, "De martyribus Palestinae et collectio antiquorum martyriorum' de Eusebio de Caesarea," La Giudad de Dios, 181 (1968), pp. 592-6oo; V. Saxer, "Les Actes des 'martyrs anciens' chez Eusèbe de Césarée et dans les Martyrologes Syriaque et Hiéronymien," AB, 102 (1984), pp. 85-95.

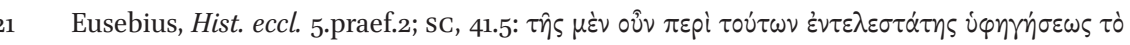

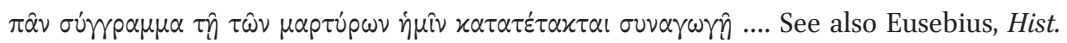
eccl.4.15.47; Eusèbe de Césarée. Histoire ecclésiastique, Livres I-IV, ed. by G. Bardy (sc, 31), Paris, 2001, rev. edn, 190. English translation in Eusebius: Ecclesiastical History, trans. by K. Lake (LCL), 2 vols, Cambridge, Mass., 1926.

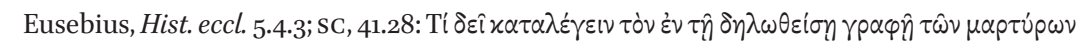

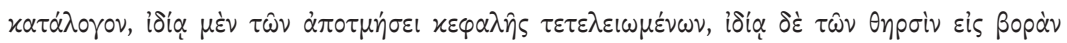

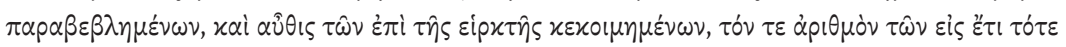

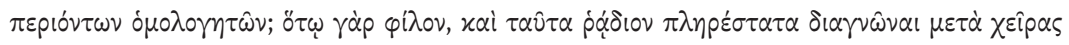


In the references in Historia ecclesiastica 5.43 , Eusebius provides the information of the original form of the list of the martyrs in Lugdunum. Why was Gregory not aware that his list was attributed to Antiquorum martyriorum collectio? We need to clarify the condition of his sources, that is, the original structure of the martyr list in Antiquorum martyriorum collectio and the data of the list which Gregory could reference instead. According to Quentin, who tried to reconstruct the original list, the existing fragments are as follows: a) Eusebius's citations in Historia ecclesiastica 5; b) Gregory's Liber in gloria martyrum 48; c) the martyrology lists that were included in the hagiographical manuscripts in Gallia (which can be roughly classified as the Velseri manuscripts and the Brussels manuscripts); d) the Gallic list of martyrs in the so-called Martyrologium Hieronimianum; and e) the list in the martyrology of Bede. Table 1 shows the names and information from these lists.

When we compare the punishments and tortures to which Historia ecclesiastica refers with the information from the lists of martyrs, we find that the original list of the martyrs in Lugdunum might have been constructed in three parts: those beheaded, those thrown to the beasts, and those who died in prison. This concurs with the information provided by Eusebius in Historia ecclesiastica. ${ }^{23}$ However, Gregory never found the common point between his lists and Eusebius' Antiquorum martyriorum collectio, that is, the 'three-part structure' of the list of martyrs. This is because Gregory read Rufinus' notoriously inaccurate Latin translation of Historia ecclesiastica.

4

The Bias of Gregory of Tours

It is well known that Gregory read Eusebius' Historia ecclesiastica translated into Latin by Rufinus, a version that was far from a literal translation. ${ }^{24}$ Gregory

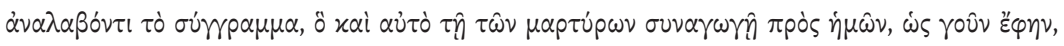

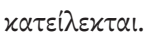

23 About the 'three-part structure' of the list of the martyrs see S. Ohtani, "Martyrs and Confessors of Lugdunum: A Validation of Eusebius's Documentation," Scr, 11 (2015), pp. 122134 .

24 From the nineteenth century onwards, scholars have criticized Rufinus. Th. Mommsen, "Einleitung zu Rufin," in: Eusebius Werke II/3: Die Kirchengeschichte, Die Lateinische Übersetzung des Rufinus, ed. by E. Schwartz and Th. Mommsen, rev. F. Winkelmann (GCS, NF 6/3), Leipzig, 1999, pp. ccli-cclxviii, esp. ccli; and J.E.L. Oulton, "Rufinus's Translation of the Church History of Eusebius," JTS, 30 (1929), pp. 150-74. Recently, however, scholars have recognized the value of Rufinus' ancient translation culture, which prioritizes the translator's overall conception. See E.C. Brooks, "Translation Techniques of Rufinus's 
seems to do not aware of the differences between the Latin translations and Greek original. ${ }^{25}$ However, Rufinus's translation of the persecution in Lugdunum deviates from the original Greek text. For example, the beasts in the arena never rush to the martyrs because they perform a miracle as saints. ${ }^{26}$ The main issue for Gregory was the reference to the record of the martyrs in Lugdunum:

Later, people count over there various glory of the martyrs. How many people slain by the sword, how many people died by the beasts, how many people died by fire, how many people died by the dirtiness of the prison. Anyone who wants to know all the matter could seek the letters. ${ }^{27}$

Rufinus omitted the title of the book that included the list of the martyrs in Lugdunum and restructured the form of the list. By inserting fire as a form of

Translations Generally," in: Studia Patristica, 17/1, ed. by E.A. Livingstone, papers presented at the Eighth International Conference on Patristic Studies, Oxford 1979, Oxford, 1982, pp. 357-364; B. Neil, "Rufinus' Translation of the Epistola Clementis ad Iacobum," Aug, 43 (2003), pp. 25-39; M. Vessey, "Jerome and Rufinus," in: The Cambridge History of Early Christian Literature, ed. by F. Young, L. Ayres, and A. Louth, Cambridge, 2004, pp. 318-327; and M. Humphries, "Rufinus's Eusebius: Translation, Continuation, and Edition in the Latin Ecclesiastical History," JECS, 16 (2008), pp. 143-164. About the differences between the Latin version and the Greek original see T. Christensen, Rufinus of Aquileia and the Historia Eccesiastica, Lib. VIII-IX, of Eusebius (Historisk-filosofisle Meddelelser, 58), Copenhagen, 1989. Cf. R. McKitterick, History and Memory in the Carolingian World, Cambridge, 2004, pp. 226-233.

25 Gregory, Libri histriarum decem 9.15, MGHSS rer. Merov, 1/1.430, writes that he learned the episode of Arius' diarrhoea from Eusebius, but this episode belongs to the additional part by Rufinus (Hist. eccl.10.14; GCS, NF 6/3, pp. 979-980.). See G. Halsall, "The Preface to Book V of Gregory of Tours' Histories: Its Form, Context and Significance," English Historical Review, 122, no. 496 (2007), pp. 297-317, at p. 316. Gregory simply accepts Rufinus and depends on his translation. In his Liber in gloria martyrum 20; MGHSS rer. Merov, 1/2.50, he cites the Latin translation about a miracle of the statue of the woman who suffered with constant bleeding (Matthew 9: 20) in Hist. eccl.7.18; Eusebius Werke II/2: Die Kirchengeschichte, ed. by E. Schwartz and Th. Mommsen, rev. F. Winkelmann (GCS, NF 6/2), Berlin, 1999, p. 673; and van Dam, Glory of Martyrs, p. 40, n. 24.

26 L. Neyrand, "Le récit de la passion des martyrs de Lyon dans la traduction de Rufin," in: Martyrs de Lyon (177), ed. by Rouge and Turcan, pp. 289-298.

27 Eusebius/Rufinus, Hist. eccl. 5.4.3; Eusebius Werke II/1: Die Kirchengeschichte, ed. by E. Schwartz and Th. Mommsen, rev. F. Winkelmann (GCS, NF 6/2), Berlin, 1999, p. 435: "Enumerant etiam post haec diversorum martyrum glorias, quanti ferro caesi, quanti bestiis, quanti ignibus, quanti etiam squalore carceris absumpti sint. quae si qui vult plenius noscere, ipsas ex integro requirat epistulas." The English translation of Historia ecclesiastica by Rufinus is the author's own translation. 
punishment, he changed Eusebius' 'three-part structure' list to a 'four-part structure' list, which is an unimaginable form that served as a source for Gregory's list of martyrs in Liber in gloria martyrum. Moreover, although Rufinus maintained the title Antiquorum martyriorum collectio in his translations (5.praef.2), it is difficult to find that "the letters"' in the Latin version of Historia ecclesiastica 5.4.3 mean the original Antiquorum martyriorum collectio. This is because, Rufinus did not use the term 'book'; rather, he used 'letters' (epistulas) after a long-cited passage of the letter (from Lugdunum).

Perhaps the list of the martyrs in Lugdunum that Gregory acquired provided no information about the relation between Eusebius and the list's origin. Gregory might have never imagined that relationship. In Liber uitae patrum, Gregory refers to his ancestor Leucadia as a descendent of a martyr from Lugdunum. In this reference, he says that the martyr Vettius Epagatus is mentioned in Eusebius' Historia ecclesiastica:

His [St. Gallus] father was called Georgius and his mother was Leucadia, of the family of Vettius Epagatus, who suffered martydom at Lyons, as Eusebius testifies in his history. ${ }^{28}$

If Gregory knew that his list of martyrs had its roots in Eusebius's writing, he would also have emphasised it when he quoted it in his Liber in gloria martyrum.

Though Gregory believed that Irenaeus was a martyr for the reason listed above, the date of Irenaeus's martyrdom was another problem. In fact, Gregory seems to separate Irenaeus from the forty-eight martyrs, because he does not list Irenaeus as one of the forty-eight martyrs. In his Liber in gloriam martyrum, Gregory seems to indicate that Irenaeus became the bishop after the persecution and suffered his own martyrdom sometime later. In my view, Gregory did not date both the so-called 'persecution in Lugdunum (in 177)' and the martyrdom of Irenaeus strictly. Let us organise the sequences of the persecutions in his eyes. In his Libri historiarum decem, Gregory refers the martyrdom of the bishop Photinus as "under Emperor Antoninus [Marcus Aurelius]". ${ }^{29}$ After the

28 Gregory, Liber uitae partum 6.1; MGHSS rer. Merov, 1/2.230: "Pater eius Georgius nomine, mater vero Leucadia ab stirpe Vetti Epagati discendens, quem Lugduno passum Eusebi testatur historia." English translation in Gregory of Tours: Life of the Fathers, trans. by E. James [TTH, 1], Liverpool, 1991, rev. edn. According to Libri historiarum decem4.5; MGHSS rer. Merov, 1/1.138, Leucadia was an ancestor of Gregory. See also Libri historiarum decem 1. 31; MGHSS rer. Merov, 1/1.24.

29 Gregory of Tours, Libri historiarum decem 1.28; MGHSS rer. Merov, 1/1.21: "Nam sub Antonini imperio ...." 
death of Photinus, Irenaeus became the new bishop of Lugdunum and the persecution occurred again. Irenaeus died in this 'second persecution'. After his martyrdom, in the 'third persecution', the forty-eight martyrs were killed. About the first persecution, Gregory says that he has the data of the martyrs in this persecution, though we do not know their names today. ${ }^{30}$ But on the contrary, Gregory could not know the names or numbers of the martyrs who were killed with Irenaeus, ${ }^{31}$ because his source, namely Passio Irenaei, did not give him any specific information about the martyrdom of Irenaeus' colleague martyrs. In the 'third persecution', however, Gregory can allege with confidence that the martyrs in this persecution were forty-eight people and the first of them was Vectius Epagatus, because this depends on the list of martyrs he acquired. From these factors, we can conclude that Gregory did not date the persecution of Lugdunum precisely. Gregory seems to give up the clear statements about the date of Irenaeus' martyrdom. He ignores the date of it at the time of Emperor Severus ("qui persectuione Severi") in Passio Irenaei. Perhaps he also ignores the mention about Irenaeus in Eusebius'/Jerome's Chronicon, which says that "Irenaeus, the bishop of Lugdunum is considered notable" under Emperor Commodus. ${ }^{32}$ The most important point which Gregory ignored is contradiction about the bishop Photinus' martyrdom. In Libri historiarum decem 29, Gregory refers Photinus' death before Irenaeus' martyrdom, but he included Photinus in the forty-eight martyrs in his Liber in gloria martyrum 48, although he said in Libri historiarum decem that the forty-eight martyrs were killed after Irenaeus' martyrdom. Both Eusebius' Historia ecclesiastica and Passio Irenaei attested that Photinus has been the predecessor bishop Irenaeus. On the other hand, the list of martyrs Gregory acquired attested the name of blessed bishop Photinus as martyrs. Gregory could not ignore these two important information but the precise dates of the martyrdom of two bishops. He might maintain his integrity in his own way.

30 Gregory of Tours, Libri historiarum decem 1.28; MGHSS rer. Merov, 1/1.21: “... quorum passionum historiae apud nos fideliter usque hodie retinentur."

$31 \quad$ Gregory of Tours, Libri historiarum decem 1.29; MGHSS rer. Merov, 1/1.22: “... quorum nec numerum nec nomina collegere potuimus ...."

32 Eusebius/Jerome, Chronicon; Eusebius Werke vII. Die Chronik des Hieronymus, ed. by R. Helm, (GCS, 47), Berlin, 2012, 2nd edn,p. 208: "Irenaeus episcomus Lugdunensis insignis habetur." 
In this article, I have attempted to clarify why Gregory of Tours might have believed Passio Irenaei and to determine the reasons he claimed that Irenaeus was a martyr, even though this conflicted with his other important source, namely, Eusebius' Historia ecclesiastica. In addition, I tackled the question on why Gregory could not have known that his list of the martyrs in Lugdunum had its roots in Eusebius' Antiquorum martyriorum collectio. The importance of Eusebius for Gregory is indubitable. Several manuscripts of Gregory's Libri historiarum decem have the title Historia ecclesiae. ${ }^{33}$ However, because of Rufinus's non-literal Latin translation and the dissipation of The Antiquorum martyriorum collectio during late antiquity and the early Middle Ages, Gregory could not have known that his source was attributed to Eusebius' ancient work. He could only find the passage of the persecution in Lugdunum in a fragment of ancient sources. Fittingly, in Libri historiarum decem, Gregory left a will behind to his succeeding bishops, instructing them not to freely cut or revise his writing, even if it was poorly written. ${ }^{34}$

TABLE 1 Reconstruction material for the list of the martyrs in Lugdunum in Eusebius' Antiquorum martyriorum collectio. Cf. H. Quentin, "La Liste des martyrs de Lyon de l'an 177," AB, 39 (1921), pp. 113-138.

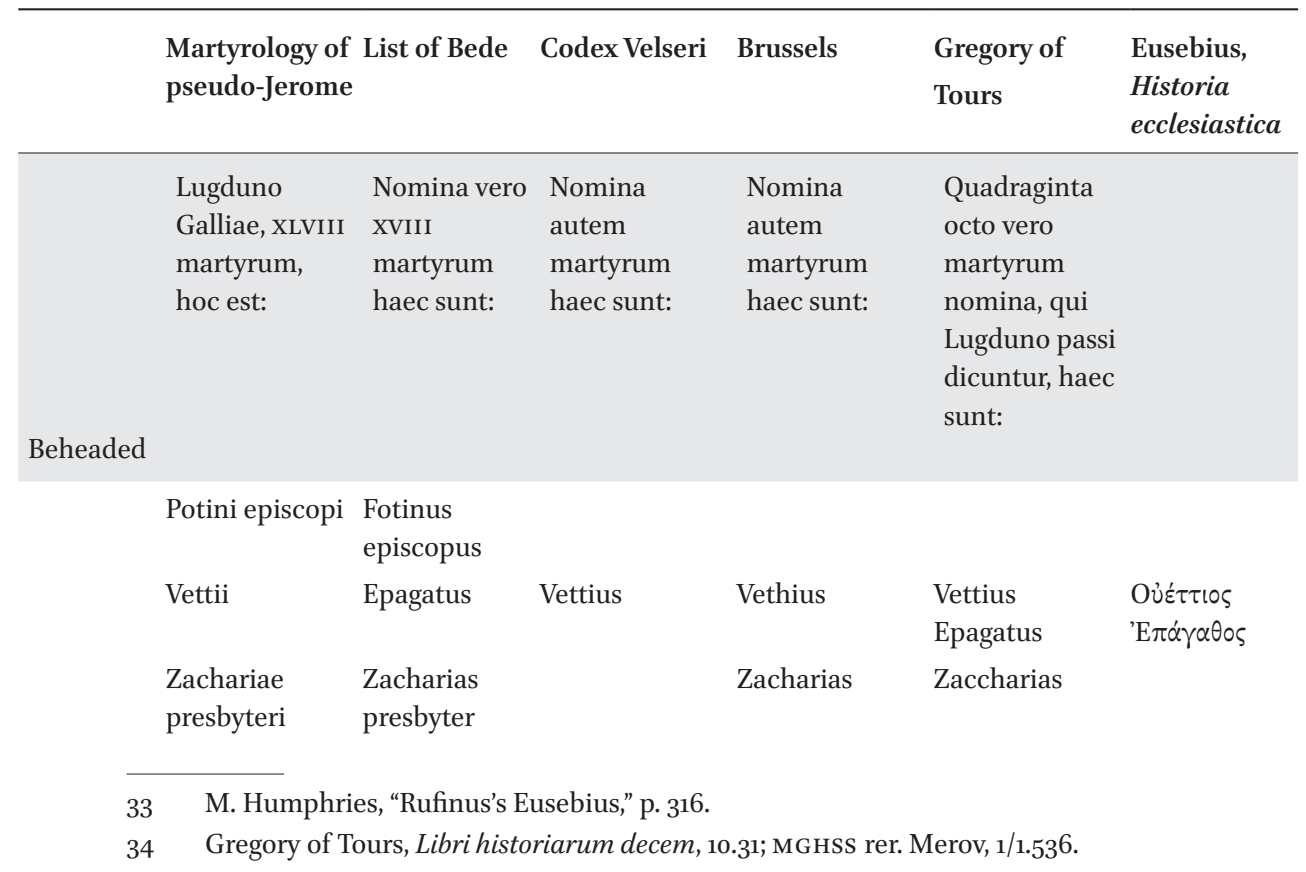




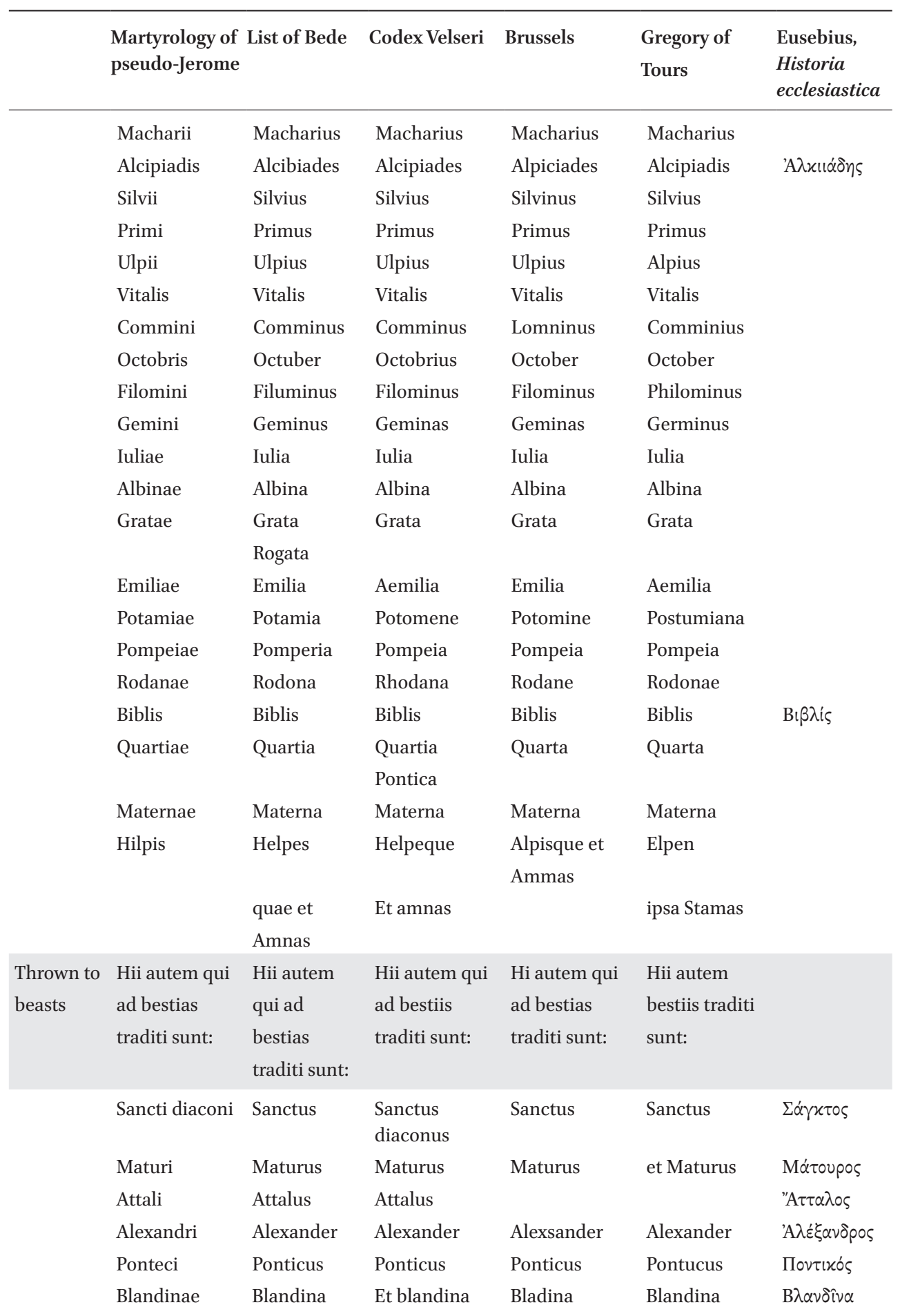


TABLE 1 Reconstruction material for the list of the martyrs in Lugdunum in Eusebius' (cont.)

\begin{tabular}{|c|c|c|c|c|c|c|}
\hline & $\begin{array}{l}\text { Martyrology of } \\
\text { pseudo-Jerome }\end{array}$ & List of Bede & Codex Velseri & Brussels & $\begin{array}{l}\text { Gregory of } \\
\text { Tours }\end{array}$ & $\begin{array}{l}\text { Eusebius, } \\
\text { Historia } \\
\text { ecclesiastica }\end{array}$ \\
\hline \multirow[t]{28}{*}{$\begin{array}{l}\text { Died in } \\
\text { prison }\end{array}$} & $\begin{array}{l}\text { Hii sunt qui in } \\
\text { carcere } \\
\text { spiritum } \\
\text { reddiderunt: }\end{array}$ & $\begin{array}{l}\text { Hii bero qui } \\
\text { carcere } \\
\text { spiritum } \\
\text { reddiderunt: }\end{array}$ & $\begin{array}{l}\text { Hii autem qui } \\
\text { in carcerem } \\
\text { spiritum } \\
\text { reddiderunt: }\end{array}$ & $\begin{array}{l}\text { Hi sunt qui in } \\
\text { carcere } \\
\text { spiritum } \\
\text { reddiderunt: }\end{array}$ & $\begin{array}{l}\text { Hii sunt qui in } \\
\text { carcerem } \\
\text { spiritum } \\
\text { reddiderunt: }\end{array}$ & \\
\hline & Aristei & Aristeus & Arestius & Arethius & $\begin{array}{l}\text { Arescius } \\
\text { et beatus } \\
\text { Photinus } \\
\text { episcopus }\end{array}$ & ПоӨعเvós \\
\hline & & & & Fotinus & Photinus & \\
\hline & Cornilii & Cornelius & Cornilius & Cornelius & Cornelius & \\
\hline & Zosimi & Zosimus & Zosimus & Cosemus & Zotimus & \\
\hline & Titi & Titus & Titus & Tytus & Titus & \\
\hline & Zotici & Zoticus & Zoticus & Loticus & Zoticus & \\
\hline & Iulii & Iulius & Iulius & Iulis & Iulius & \\
\hline & Appollonii & Appollonius & Apollonius & Apollonius & & \\
\hline & Geminiani & Geminianus & Germinianus & Geminianus & & \\
\hline & Iuliae & Iulia & Iulia & Iulia & & \\
\hline & Ausonae & Ausona & Auxentia & Ausone & & \\
\hline & item Emiliae & Emilia & Item aemelia & Emilia & Aemelia & \\
\hline & Iamnicae & Iamnica & Gamnica & Imanica & Gamnitae & \\
\hline & Pompeiae & Pompeia & Item pompeia & Pompeia & Pompeia & \\
\hline & Domnae & Domna & Domna & Domna & Alumna & \\
\hline & Amiliae & & Mamilia & Mammilia & Mamilia & \\
\hline & Iustae & Iusta & Iusta & Iusta & Iusta & \\
\hline & Trofimae & Trofima & Trofimae & Trofome & Trifimae & \\
\hline & Antoniae & Antonia & Et antonia & et Antani & Antonia & \\
\hline & Hii omnes & Hi omnes & & & & \\
\hline & famuli Christi, & famuli & & & & \\
\hline & sub Antonio & Christi sub & & & & \\
\hline & imperatore & praefato & & & & \\
\hline & sunt coronati. & imperatore & & & & \\
\hline & & pariter & & & & \\
\hline & & coronati & & & & \\
\hline & & sunt. & & & & \\
\hline
\end{tabular}

